\title{
LOFTUSIA CF. ANATOLICA HORIZON IN UPPER MAASTRICHTIAN LIMESTONES OF THE EASTERN GREECE PLATFORM (MOUNT PTOON, BOEOTIA, GREECE): PALAEOBIOGEOGRAPHICAL REMARKS
}

\author{
Zambetakis - Lekkas A. and Kemeridou A. \\ National and Kapodistrian University of Athens, Faculty of Geology, Dep. of Historical Geology \\ and Paleontology, Panepistmioupoli Zografou, 15784 Athens. E-mail: zambetaki@geol.uoa.gr
}

\begin{abstract}
Researches on upper Cretaceous limestones from the Eastern Greece platform in the area between Kokkinon and Akrefnion (Boeotia, Greece) revealed the presence of a horizon rich in Loftusia cf. anatolica (foraminifer). In this horizon, of late Maastrichtian age, L. cf. anatolica is associated with debris of Rudists, Orbitoides media, O. apiculata, O. gensacicus, Siderolites calcitrapoides, Omphalocyclus macroporus, Hellenocyclina beotica, Miliolidae, Dasycladaceae and echinoderms. It is found in an undisturbed sequence of limestones, where both the underlying and the overlying horizons are of the same facies and contain debris of Rudists. Hellenocyclina beotica, Orbitoides media, Siderolites calcitrapoides, Sulcoperculina sp., Rotaliidae, Mélobesiées, Nummofallotia sp., echinoderms. L. cf. anatolica is confined in the above mentioned horizon and it is found neither in the underlying nor in the overlying beds. This facies reflects an outer shelf environment in front of the rudist reefs.

It is the first time that this species is reported in situ in Greece in an undisturbed stratigraphic sequence of upper Cretaceous limestones up to Paleocene flysch.
\end{abstract}

KEY WORDS: Loftusia cf. anatolica, Maastrichtian, paleobiogeography, Eastern Greece platform, Boeotia, Greece.

\section{INTRODUCTION}

Loftusia is a benthic foraminifer of Maastrichtian, known from outer platform facies of the Tethys Ocean. The genus is abundant in arabo-iranian platforms, rare in eastern Mediterranean and totally absent in western Mediterranean (Fig. 7).

In Greece it has so far been reported from two sites:

- On Kassidiaris mount (MK in Fig.7) as debris in bioclastic upper Cretaceous limestones of the internal zones (Ferrière, 1982),

- On mounts Valtou (Gavrovo zone, MV in Fig.7) in an occasionally bioclastic conglomerate which is limited by faults that prohibit us from observing its relation with the surrounding formations (Fleury et al., 1990).

In the area of Boeotia, on mount Ptoon (Fig. 1), a horizon rich in Loftusia cf. anatolica has been found (MP in Fig. 7) in an undisturbed sequence of upper Cretaceous limestones up to Paleocene flysch of the Eastern Greece zone. This recovery is considered very important for the paleogeography of the Tethys Ocean during late Cretaceous.

\section{STRATIGRAPHIC DESCRIPTION}

This section was realized along the road that from Kokkinon (Boeotia) leads to Akraifnion. More specifically it begins at the point where the road "Megali Rachi" is being constructed, $2 \mathrm{~km}$ before Akraifnion (Fig. 1). 


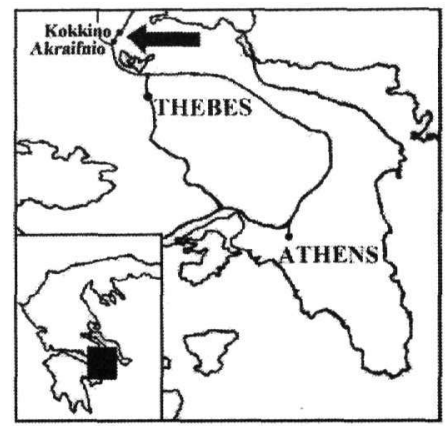

Fig. 1 Location of the study area.

From bottom to top we observed the following formations (Fig.2):

A: $20 \mathrm{~m}$ of gray, medium bedded to massive limestones, grainstone-rudstone with debris of Rudists (Fig.3a).

B: $3 \mathrm{~m}$ of light gray massive limestones, floatstone with Orbitoides tissoti (Fig.3b), Orbitoides media, Lepidorbitoides sp., Siderolites calcitrapoides (Fig.3b), Sulcoperculina sp. Goupillaudina sp., Rotaliidae, Mélobesiées and echinoderms. At the upper part only abundant shells of Rudists are observed.

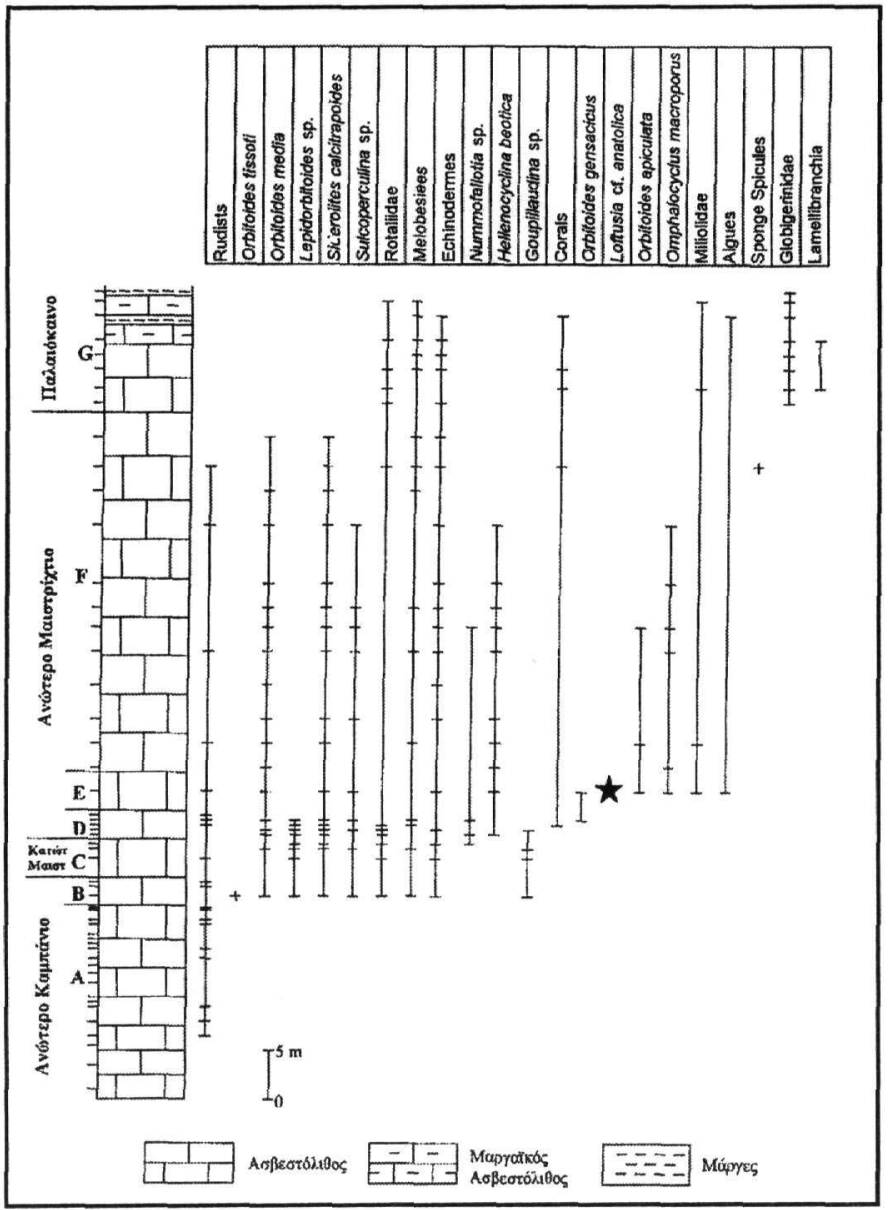

Fig. 2. Stratigraphic columr. 
C: $4 \mathrm{~m}$ of light gray massive limestones, packstone-grainstone, with debris of Rudists, Orbitoides media, Lepidorbitoides sp., Siderolites calcitrapoides (Fig.3c), Sulcoperculina sp., Nummofallotia sp., Goupillaudina sp., Rotaliidae, Mélobesiées and echinoderms.

D: $3 \mathrm{~m}$ of light gray massive limestones, packstone-floatstone to grainstone, with debris and shells of Rudists, Hellenocyclina beotica, Orbitoides media, Orbitoides gensacicus (Fig.3d), Lepidorbitoides sp., Siderolites calcitrapoides, Sulcoperculina sp., Nummofallotia sp. (Fig. 3d), Goupillaudina sp., Rotaliidae, Mélobesiées, echinoderms and corals.

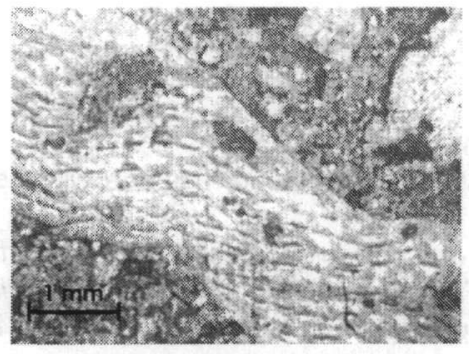

(a)

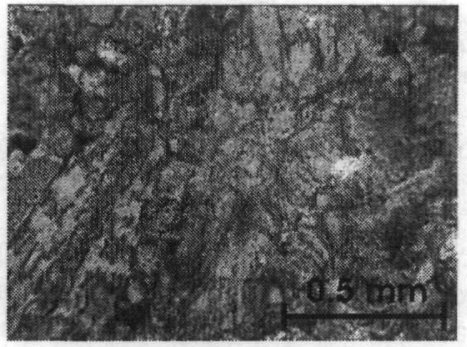

(b)

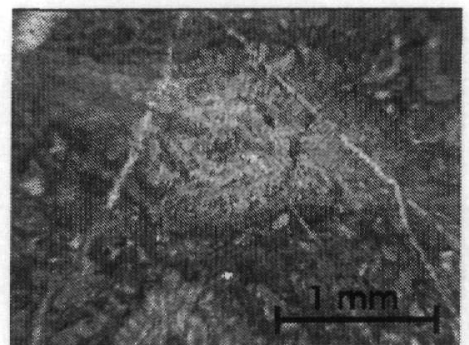

(c)

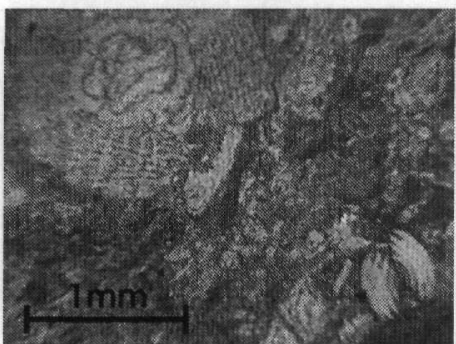

(d)

Fig. 3. (a) Rudist debris. (b) Orbitoides tissoti, Siderolites calcitrapoides. (c) Siderolites calcitrapoides. (d) Orbitoides gensacicus, Nummofallotia sp.

E: $4 \mathrm{~m}$ of light gray, thickly bedded limestones, floatstone, with debris of Rudists, Loftusia cf. anatolica (Fig. 4a, b), Orbitoides media (Fig. 4b), Orbitoides apiculata (Fig. 4b), Orbitoides gensacicus, Siderolites calcitrapoides, Omphalocyclus macroporus (Fig. 5a), Hellenocyclina beotica, Sulcoperculina sp., Miliolidae, echinoderms and algues.

F: $37 \mathrm{~m}$ of light gray, thickly bedded limestones, packstone-grainstone, with debris of Rudists, Hellenocyclina beotica (Fig. 5b), Orbitoides media, Siderolites calcitrapoides, Orbitoides apiculata, Omphalocyclus macroporus, Sulcoperculina sp., Nummofallotia sp., Mélobesiées, Rotaliidae, Miliolidae, echinoderms and corals.

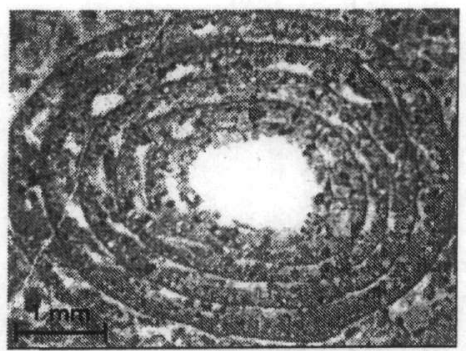

(a)

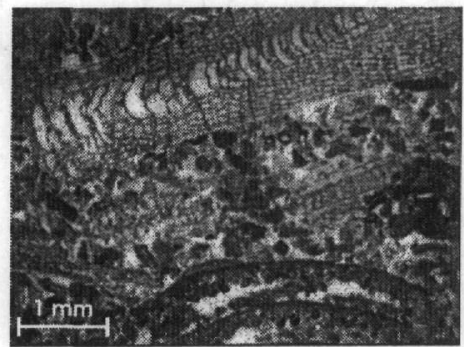

(b)

Fig. 4. (a) Loftusia cf. anatolica. (b) Loftusia cf. anatolica, Orbitoides media, Orbitoides apiculata, Omphalocyclus macroporus. 


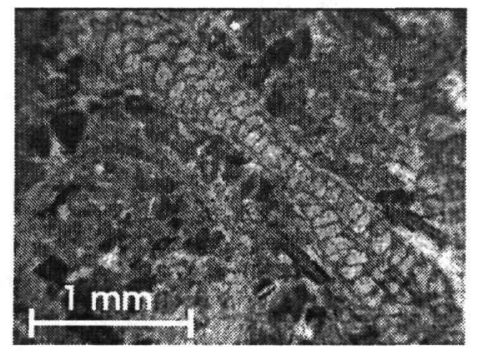

(a)

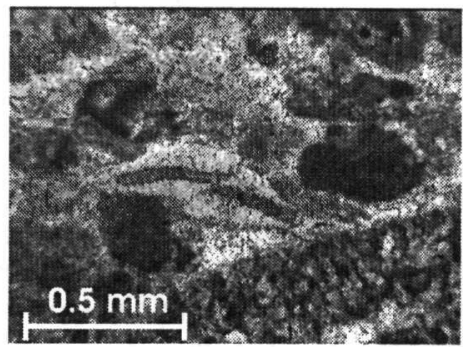

(b)

Fig.5. (a) Omphalocyclus macroporus, (b) Hellenocyclina beotica.

G: $13 \mathrm{~m}$, of light gray, thickly bedded limestones, packstone-wackestone, with Globigerinidae (Fig. 6a), Rotaliidae, Mélobesiées (Fig. 6b), spicules and large shells of echinoderms (Fig. 6b), Miliolidae, corals, algues and debris of Lamellibranches. In the upper part, thin bedded marly limestones and marls are followed by flysch sedimentation.

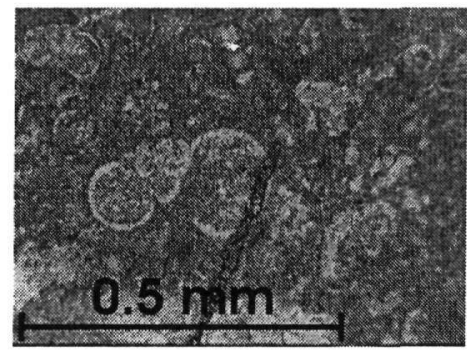

(a)

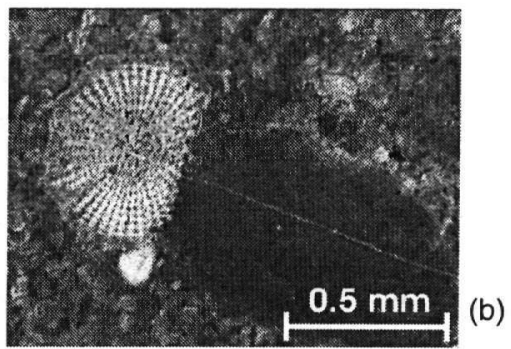

Fig. 6. (a) Globigerinidae, (b) Mélobésiées, spicule of echinoderm.

We observe that Loftusia appears in relative abundance in a thin horizon (approximately $4 \mathrm{~m}$ ) of late Maastrichtian age (association with Hellenocyclina beotica) and it is found neither in the underlying nor in the overlying beds. That could explain the rarity of the references of the genus.

In the study area the facies that contain Loftusia reflect an environment in the outer platform. The vicinity to the rudist reefs is indicated by the abundant debris and entire shells of Rudists in the horizon that underlies the one with Loftusia. This environment is in agreement with what is reported in the international literarure concerning the biotope of the genus Loftusia.

\title{
3 MICROPALEONTOLOGICAL REMARKS
}

\author{
Order: Foraminiferida EICHWALD 1830 \\ Suborder: Textulariina DELAGE \& HEROUARD 1896 \\ Superfamily: Loftusiacea BRADY 1884 \\ Family: Loftusiidae BRADY 1884
}

Genus: Loftusia BRADY (in Carpenter \& Brady 1870)

Type species: Loftusia persica BRADY (in Carpenter \& Brady 1870)

Loftusia BRADY 1870 is a benthic planispiral foraminifera. It has a fusiform, ovoid, globose or nautiloid test. The wall of the spire is perforate, calcareous and alveolar with an arenaceous endoskeleton. It is tightly coiled with regular whorls whose thickness increases gradually from center to periphery. Primary, longitudinal, oblique septa divide the whorls into chambers with labyrinthic, endoskeletal structure. The last is composed of radially set pillars. Transverse secondary or partial septa may be formed from the fusion of pillars. Across the primary septa and arranged in transverse rows there are numerous apertures. 
The determination of the species so far described is primarily based on size. Thus small, medium and large size species are distinguished (Brady, 1869 in Carpenter \& Brady, 1870; Douvillé, 1904; Cox, 1937; Grubic, 1958; Meric 1965a, b, 1967, 1979; Al Omari \& Sadek, 1976, El Asa'ad, 1989, Meric \& Avsar, 1992).

Cox (1937) studied the Loftusia from Persia providing a historical review on the genus in detail. Furthermore based on measurements of their external dimensions e.g. maximum diameter, L/D ratio, he made up a table of the different species of the genus.

Loftusia anatolica MERIC 1965 was defined as a medium sized species with rounded poles. The measurements of the size and internal structures of $L$. anatolica and the other species of the genus as well as of our specimens are shown in Table 1. The specimens observed in our samples are megalospheric. The test is fusiform with alveolar structure and it has rounded poles.

Tab.1. Measurements on species of Loftusia (after Henson, 1948; Meric, 1965, 1979; Inan, 1988; El-Asa'ad, 1989). Measurements on specimens of $L$. cf. anatolica determined in Ptoon are included.

\begin{tabular}{|c|c|c|c|c|c|c|c|c|}
\hline $\begin{array}{l}\text { Species } \\
\text { of } \\
\text { Loftusia }\end{array}$ & $\begin{array}{l}\mathrm{N}^{0} \text { of } \\
\text { tours }\end{array}$ & $\begin{array}{l}\text { Length } \\
(\mathrm{mm})\end{array}$ & $\begin{array}{l}\text { Diameter } \\
(\mathrm{mm})\end{array}$ & $\begin{array}{c}\text { Height of } \\
1^{\text {st }} \text { tour } \\
\text { (mm) }\end{array}$ & $\begin{array}{l}\text { Height of } \\
\text { last tour } \\
(\mathrm{mm})\end{array}$ & $\begin{array}{l}\text { Diam. of } \\
\text { embr. } \\
\text { chamber } \\
(\mathrm{mm})\end{array}$ & $\begin{array}{l}\mathrm{N}^{\circ} \text { of } \\
\text { septa } \\
\text { of } 1^{\text {st }} \\
\text { tour }\end{array}$ & $\begin{array}{l}\mathrm{N}^{0} \text { of } \\
\text { septa } \\
\text { of las } \\
\text { tour }\end{array}$ \\
\hline anatolica & $6-7$ & $\begin{array}{c}16.1-22 \\
\text { max-ave-min }\end{array}$ & $\begin{array}{c}4.7-6.1 \\
\text { Max-ave-min }\end{array}$ & $0.2-0.4$ & $0.3-0.4$ & $0.9-1.4$ & $8-11$ & $8-22$ \\
\hline arabica & 10 & $58-33.9-16.5$ & $6-3.9-2.1$ & - & - & - & - & - \\
\hline baykali & $2-3$ & $2.3-4.2$ & $1.6-2.4$ & 0.3 & $0.2-0.3$ & $0.4-0.8$ & $6-7$ & $9-10$ \\
\hline $\operatorname{coxi}$ & 3 & $\begin{array}{c}\max : 6.1 \\
\text { max-ave-min }\end{array}$ & $\begin{array}{c}\text { Max: } 3.3 \\
\text { max-ave-min }\end{array}$ & - & 0.55 & $0.33-0.4$ & - & $12-13$ \\
\hline $\begin{array}{l}\text { elongata } \\
\text { ketini }\end{array}$ & 18 & $118-55.5-12$ & $33-12.3-5.6$ & - & - & - & - & - \\
\hline (forme A) & $1.5-2.5$ & $1.8-5.3$ & $1.4-2.5$ & $0.35-0.39$ & $0.31-0.39$ & $0.5-1.0$ & $4-5$ & $9-10$ \\
\hline $\begin{array}{l}\text { (forme B) } \\
\text { minor }\end{array}$ & $8-10$ & $23.9-41.8$ & $5.2-10.7$ & $0.43-0.78$ & $0.43-0.67$ & - & $4-5$ & $23-25$ \\
\hline (forme A) & $6-7$ & $2.75-7.5$ & $2.30-4.32$ & $0.14-0.2$ & $0.16-0.38$ & - & - & - \\
\hline (forme B) & $2-2.5$ & $\begin{array}{c}1.5-1.7 \\
\text { max-ave-min }\end{array}$ & $\begin{array}{c}1.52-1.8 \\
\text { max-ave-min }\end{array}$ & $\sim 0.3$ & $0.22-0.24$ & $0.2-0.8$ & - & - \\
\hline morgani & 16 & $44.5-27-6$ & $8-5.8-3$ & - & - & - & - & - \\
\hline $\begin{array}{l}\text { L. cf. } \\
\text { anatolica } \\
\text { in Ptoon }\end{array}$ & $5-7$ & 8.56 & $3.2-4.04$ & $0.2-0.36$ & $0.28-0.4$ & $0.84-2$ & & \\
\hline
\end{tabular}

Thus according to the measurements, our specimens are included in the group of medium-sized species of Loftusia. Based on previous data we conclude that the species with which our specimens present the greatest resemblance is Loftusia anatolica MERIC 1965. It is a species of medium size and it has been described only from megalospheric forms. The measurements in our specimens present small deviations from the typical $L$. anatolica, mainly in the total length, which was measured in only one specimen, and the diameter. Both were found smaller while the diameter of the embryonic chamber appears bigger. The observed deviations could not lead us to the identification of a new species due to lack of a sufficient number of specimens.

Al-Omari \& Sadek (1976) investigated microscopically and statistically specimens of Loftusia from the Maastrichtian of Northern Iraq (Aqra Formation). They noticed that during this period the genus exhibited a gradual increase in size (length and diameter). Thus, they recognized an evolutionary line for the development of Loftusia considering the forms recorded from Cox (1937) as the early stages of the genus' development. In addition they recorded a tendency for tighter forms during the transition from Mid to Late Maastrichtian.

Meriç et al. (2001) studied the palaeogeographical distribution of the species of Loftusia on the Gondwanian and Laurasian platforms during the Maastrichtian based on the plate tectonic reconstructions of Sengör \& Yilmaz (1981). The authors identified three main Loftusia groups according 
to previous data on their dimensions: small, medium and large. Meriç et al. (2001) also noted that loftusiids show dimorphism with most of the Loftusia species having been identified from either megalospheric $(A)$ or microspheric $(B)$ (only few) forms. Both $(A)$ and $(B)$ forms are seen in only a few species.

\section{PALEOECOLOGICAL AND PALEOGEOGRAPHICAL REMARKS}

The genus Loftusia is already known since the 19th century. It is abundant in arabo-iranian platforms, rare in eastern Mediterranean and totally absent in western Mediterranean (fig. 7). It is reported from:

-Iran: Brady, 1869 in Carpenter \& Brady, 1870; Douvillé, 1904; Cox, 1937 (ZA); Bozorgnia, 1964 (ZA); Sampo, 1969 (ZA).

-Iraq: Henson, 1948, 1950 (IN); Al Omari \& Sadek, 1976 (IN); Schroeder \& Darmoian, 1977 (IN); Al Naqib, 1967 (IN).

-Oman: Kuhn, 1929; Philip \& Platel, 1987; Babinot \& Bourdillon de Grissac, 1989.

-Saudi Arabia: Powers, 1968 (AS).

-Dinarides: Milovanovich, 1935, 1938, Serbia; Grubic, 1958, 1962 Serbia; Drobne \& Hottinger, 1971 (SO); Chorowicz, 1977 (PK); Radoicic, 1980.

-Apennines: Molinary \& Tilia, 1976; Chiocchini et al. , 1976; Chiocchini \& Mancinelli, 1977 (ML); Carbone \& Sirna, 1981 (ML).

-Taurides and Pontides: Meric, 1965 (TO); Meric \& Mojab, 1977; Poisson, 1977 (NL); Meric, 1991.

-Syria: Sadek, 1979 (SY) and

-Hellenides: Ferriere, 1982 (MK); Fleury et al., 1990 (MV) and present paper (MP).

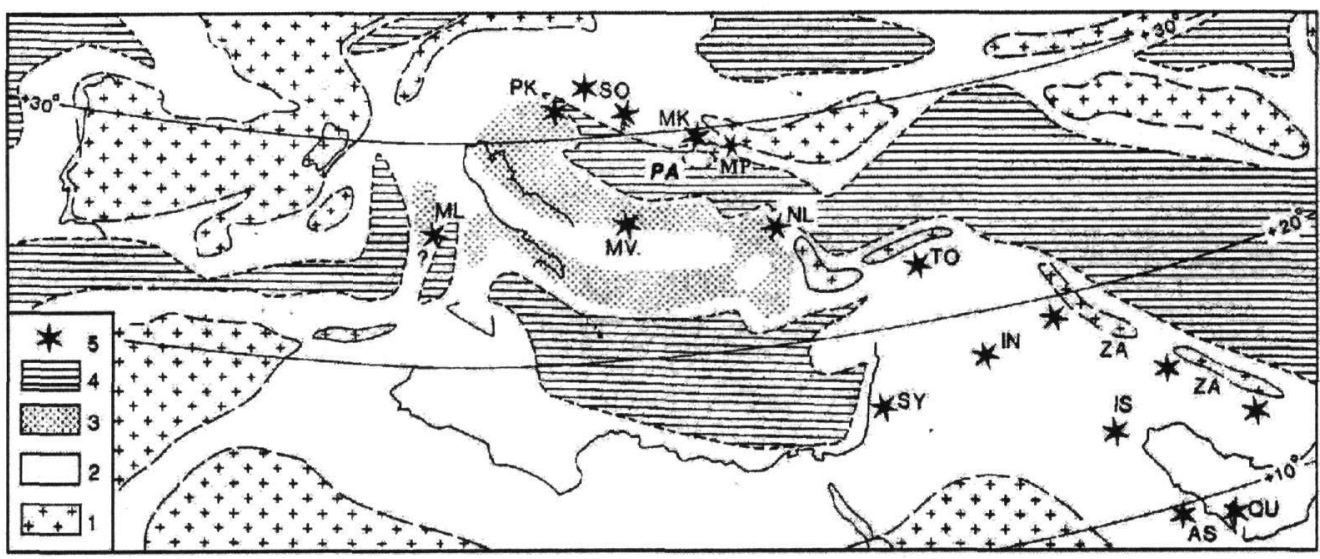

Fig. 7. Palinspastic distribution of the occurrences of the genus Loftusia. The pairs of letters correspond to the localities mentioned in the text (PA: Mount Parnassus, Greece) (from Fleury et al. 1990 , modified).

1: land areas, 2: shelf and slope, 3: Adriatic-Aegean carbonate platforms, 4: deep water basins, 5: Loftusia occurrences.

In the majority of the sites, Loftusia is either transported (Chorowicz, 1977; Poisson, 1977; Ferriere, 1982) or the beds that enclose it are not in stratigraphic continuity with the underlying and the overlying formations. Thus:

On mounts Valtou (Gavrovo zone) (Fleury et al., 1990) Loftusia is found in a conglomerate which comes in contact, by faults, with limestones probably of Cenomanian age, as well as with $\mathrm{Pa}$ leocene breccias with Madrepores. The Loftusia shells are included in a grainstone-rudstone facies along with debris of Rudists, Orbitoides sp. (large size, up to $16 \mathrm{~mm}$ ), Lepidorbitoides $\mathrm{sp}$. and other 
benthic foraminifers. The depositional environment at the margin of the platform, during Campanian-Maastrichtian is the contribution of this recovery on mounts Valtou.

Meric (1965a) found abundant specimens of Loftusia in eastern Turkey, among which he determined $L$. anatolica n.sp., in conglomeratic limestones of Maastrichtian age. The Loftusia shells usually constitute elements of the conglomerate therefore can be considered as transported. The Lutetian uncomformably overlies the Maastrichtian beds.

Al Omari \& Sadek (1976) studied the evolution of the Loftusia species in a Maastrichtian sequence in northern Iraq. Nevertheless they do not provide information concerning its stratigraphic relation with the surrounding formations.

Henson (1950) notas that in the Aqra formation in northern Iraq, the compact reefal rudistic limestones pass into shallow facies of the reefal margin with Loftusia, Omphalocyclus, Orbitoides.

In Boeotia, the Loftusia are found in a calcareous Upper Maastrichtian horizon in a stratigraphic sequence of upper Campanian up to Paleocene age. The Loftusia horizon overlies a horizon with abundant Rudist shells and is associated with Orbitoides media, Orbitoides apiculata, Siderolites calcitrapoides, Omphalocyclus macroporus, Hellenocyclina beotica, Sulcoperculina sp., Miliolidae and echinoderms. The same fossils, but without the Loftusia, are also found in the overlying horizon, along with abundant large shells of echinodermes. This facies reflects an outer shelf environment in front of the rudist reefs of the Maastrichtian.

\section{CONCLUSIONS}

Loftusia cf. anatolica horizon of late Maastrichtian age is for the first time found in Greece in a continuous undisturbed sequence of upper Cretaceous limestones up to Paleocene flysch in Eastern Greece platform in Boeotia. Associated with debris of Rudists, Orbitoides media, O. apiculata, O. gensacicus, Siderolites calcitrapoides, Omphalocyclus macroporus, Hellenocyclina beotica, Miliolidae, Dasycladaceae and echinoderms it reflects an outer shelf environment in front of rudist reef.

\section{REFERENCES}

Al Naqib, K.M. 1967. Geology of the Arabian Peninsula, southwestern Iraq. Geol. Surv. Prof. Paper 560 G., U.S. Gov. Print. Off.., Washington.

Al Omari, F. and Sadek, A. 1976. Loftusia from northern Iraq. Rev. Esp. Micropal., Madrid, 8, 1, pp. 57-67.

Babinot, J.F. and Bourdillon-de-Grissac, C. 1989. Associations d' Ostracodes de l' Albien-Maastrichtien du Dhofar (Oman). Affinités paléobiogéographiques et implications géodynamiques. Bull. Soc. Géol. Fr., Paris (8), V. 2, pp. 287-294.

Bozorgnia, F. and Benafti, S. 1964. Microfacies and microorganisms of Paleozoic through Tertiary sediments of some parts of Iran. 16 pp., 108 pls (National Iranian Oil Company, Tehran).

Carbone, F. and Sirna, G. 1981. Upper Cretaceous reef models from Rocca di Cave and adjacent areas in Latium, central Italy. In: TOOMEY D.F. Ed., European fossil reef models. Soc. Econ. Paleontol. Mineral. spec. publ., Tulsa, 30, pp. 427-445.

Carpenter W.B. and Brady, H.B. 1870. Description of Parkeria and Loftusia, two gigantic types of arenaceous foraminifera. Roy. Soc. London, Phil. Trans., London, England, vol. 159, p. $739-751$.

Chiocchini, M. and Mancinelli, A. 1977. Microbiostratigrafia del Mesozoico in facies di piatta forma carbonatica dei Monti Aurunci (Lazio meridionale). Studi geol. Camerti, Camerino, III, (1977), pp. 109-152.

Chiocchini, M., Molinari, V. and Tilia, A. 1976. Aperçu sur la biostratigraphique des sédiments carbonatés de plateforme du Latium centre-méridional (Italie). Première partie: Crétacé. VII Colloque Africain de Micropaléontologie, Ile-Ife, Nigeria, pp. 16-28.

Chorowicz, J. 1977. Etude géologique des Dinarides le long de la structure transversale Split-Karlovac (Yougoslavie). Soc. Géol. Nord Publ, Lille, 1,331 p., Thèse Sci., Paris, 1977.

Cox, P. 1937. The genus Loftusia in southwestern Iran. Eclogae Geologicae Helvetiae, 30, 431-450.

Douvillé, H. 1904. Les explorations de M de Morgan, en Perse. Bulletin dę la Société Géologique de france 4, 539-553.

Drobne, K. and Hottinger, L. 1971. Broeckinella und Saudia aus dem Nordwestlichen Teil Jugoslawiens. Razprave Slov. akad. znam. umet., Ljubljana, class. 4, XIV, 7, pp. 215-238.

El-Asa'ad, G.M. 1989. Loftusia arabica sp. nov. (Foraminiferida) from the Maastrichtian of central Saudi Arabia. J. Micropaleontol., 8(1), p. 49-54. 
Ferrière, J. 1982. Paléogéographies et tectoniques superposées dans les Hellenides internes : les massifs de I' Othrys et du Pélion (Grèce continentale). Soc. géol. Nord Publ., Lille, 8, 970 p., Thèse Sci., Lille, 1982.

Fleury, J.J., Mavrikas, G. and Baudin, F. 1990. Paléobiogéographie du genre Loftusia, foraminifère du Crétacé terminal de la Téthys. Bull. Soc. Géol. France, (8), t. VI, $n^{\circ}$ 3, pp. 487-495.

Grubic, A. 1958. O rodu Loftusia Brady (le genre Loftusia Brady). Bulletin du Service de Géologie et Géophysique, Republique de Serbie 16, 45-55.

Grubic, A. 1962. Loftusia morgani Douvillé 1904 aus dem Cerevic-Bach (Fruska Gora, Yugoslavien). University of Beograd, Transactions of the Mining and Geological Faculties, pp. 41-50.

Henson, F.R.S. 1948. Larger imperforate foraminifera of south-western Asia. Families Lituolidae, Orbitolinidae and Mendrosipinidae, British Museum (Natural History), London.

Henson, F.R.S. 1950. Cretaceous and Tertiary reef formations and associated sediments in Middle East. Am. Ass. Petrol. Geol. Bull., Tulsa, 34, 2, pp. 215-238.

Inan, N. 1988. Sur la présence de Smoutina cruysi DROOGER dans le Maastrichtien supérieur de Sivas (Est de la Turquie). Rev. de Paléob., vol. 7, n॰2, pp. 467-475, Genève.

Kuhn, O. 1969. Beitrage zur Paläontologie und Stratigraphie von Oman (Ost-Arabien). Annale Naturhistorische Museum Wien 43, 13-33.

Meriç, E. 1965a. Sur deux espèces de Loftusia et un nouveau genre, Asterosomalina. Rev. Micropal., vol. 8, $\mathrm{n}^{\circ}$ 1. pp. 45-52.

Meriç, E. 1965b. Etude géologique et paléontologique de la région entre Kahta et Memrut dag. Rev. Fac. Sci. Univ. Ist., série B, t. 30, no 1-2, pp. 55-107, pl. 1-20.

Meriç, E. 1967. Sur quelques Loftusiidae et Orbitoididae de la Turquie. Rev. Fac. Sci. Univ. Ist., série B, t. 32, $\mathrm{n}^{\circ}$ 1-2, pp. 1-58, pl. 1-36.

Meriç, E. 1979. Loftusia ketini (Foraminifère) nouvelle espèce du Maestrichtian. Revista Española de Micropaleontología 11, pp. 509-516.

Meriç, E. 1991. On the presence of Loftusia anatolica Meriç in the Maastrichtian sequence of Rava S. Maria (Monts Lepini, Latium Centrale-Meridionale, Italy). Bulletin of the Technical University, Istabul 44, 97-102.

Meriç, E., and Avşar, N. 1992. Loftusia turcica Meriç and Avşar n. sp. from the Maastrichtian of eastern Turkey (southeast Elazıg). Micropaleontology 38, pp. 303-309.

Meriç, E., Ersoy S., and Görmüs M. 2001. Palaeogeographical distribution of the species of Loftusia (Foraminiferida) in the Tethyan Ocean during the Maastrichtian (Late Cretaceous). Cretaceous Research, 22, 353-364.

Meriç, E. and Mojab, F. 1977. World-wide geographical distribution of the species of the foraminiferal genus Loftusia. Istabul Universitesi, Fen Fakiiltesi Dergisi, Seri B 42, 143-155.

Milovanovich, B. 1935. Loftusia morgani Douvillé du Maastrichtian de la Serbie Orientale. Annals Géologiques de la Peninsule Balkanique, Beograd 12, 246-252.

Milovanovich, B. 1938. Sloveji sa Loftusia i problem postjanja marinskog eocena v Zapadnoj Srbije. Vesnik Geologii Instituta, Beograd 6, 121-134.

Molinari, P.V. and Tilia, Z.A. 1976. Niveau à Rhapydionina liburnica (Stache) dans la succession Sénonienne des Montes Lepini (Latium Centre-Méridional). VII Colloque African de Micropaléontologie, Ile-lfe, Nigeria, 16-28 Mars, 1976.

Philip, J. and Platel, J.P. 1987. Sur la présence du genre Torreites (rudiste de la Province Caraïbe) dans le Campanien du Dhofar (sud de l' Oman) : conséquences sur l' évolution paléobiogéographique du Pacifique et de l' océan Indien au Crétacé. C. R. Acad. Sci., Paris, 304, II, 12, pp. 679-684.

Poisson, A. 1977. Recherches géologiques dans les Taurides occidentales (Turquie), 795 p. Thèse Paris-Sud (Orsay).

Powers, R.W. 1968. Lexique stratigraphique international, vol. III (Asie), fasc. 10b 1 : Arabie Saudite. CNRS, Paris.

Radoicic, R. 1980. Micropaleontological aspect of Stira Limestone (Gucevo Region). GLAS CCCXVIII, Acad. serbe Sciences et Arts. Class Sc. Nat. et math., Zagreb, 46, pp. 95-109.

Sadek, A 1979. The Campanian-Maestrichtian sediments in East Mediterranean and parts of North Africa. VI Coll. geol. Aegean Region, Athènes, (1977), II, pp. 827-834.

Sampo, M. 1969. Microfacies and microfosssils of the Zagros area, southwestern Iran (from pre-Permian to Miocene), 207 pp. (International Sedimentary Petrographical Series, Leiden 12).

Schroeder, R. and Darmoian, S.A. 1977. Gyroconulina columellifera n.gen. n.sp., a complex ataxophragmiid Foraminifer from the Aqra Limestone (Maastrichtian) of northern Iraq. Boll. Soc. Paleont. Ital., Bologne, 16, 1, pp. 117-123.

Sengör, A. and Yilmaz, Y. 1981. Tethyan evolution of Turkey: a plate tectonic approach. Tectonophysics, vol. 75, p. $181-241$. 